\title{
Association between Human T-Cell Lymphotropic Virus Type 1 and 2 (HTLV 1/2) infection and tuberculosis: systematic review and meta-analysis
}

Sérgio Arruda ${ }^{1,2^{*}}$, Camila Loureiro ${ }^{1}$, Marcos Almeida ${ }^{1}$, Dayana Mendes ${ }^{2}$, Maria F R Grassi ${ }^{1,2}$, José R Lapa ${ }^{3}$, Afrânio Kritski ${ }^{3}$, Kristien Verdonck ${ }^{4,5}$, Eduardo Gotuzzo ${ }^{4}$, Bernardo Galvão-Castro ${ }^{1,2^{*}}$

From 15th International Conference on Human Retroviruses: HTLV and Related Viruses

Leuven and Gembloux, Belgium. 5-8 June 2011

\section{Background}

HTLV-1 infection alters the immune function and increases the risk of several infectious diseases. In this meta-analysis, we assess the association between HTLV$1 / 2$ and active tuberculosis (TB).

\section{Methods}

Four databases were searched for relevant articles that describe the frequency of HTLV- $1 / 2$ infection among TB patients and control groups of healthy individuals or patients without a history of TB. Data were analyzed using the EasyMA software.

\section{Results}

The search yielded two hundred and eight articles. Six met the inclusion criteria and were included in the meta-analysis. The estimated relative risk of HTLV- $1 / 2$ infection in TB patients was 3.25 times higher than in the population based control groups.

\section{Conclusion}

Patients with active TB have a higher risk of HTLV- 1/2 infection. Prospective studies involving latent tuberculosis infection (LTBI) in HTLV-1-infected individuals are necessary to evaluate the potential benefit of $\mathrm{TB}$ chemoprophylaxis.

\section{Author details}

${ }^{1}$ Escola Bahiana de Medicina e Saúde Pública, Salvador, Bahia, Brazil. ${ }^{2}$ Laboratório Avançado de Saúde Pública, Centro de Pesquisas Gonçalo Moniz, Fiocruz, Salvador, Bahia, Brazil. ${ }^{3}$ Universidade Federal do Rio de

* Correspondence: bgalvao@bahia.fiocruz.br

${ }^{1}$ Escola Bahiana de Medicina e Saúde Pública, Salvador, Bahia, Brazil

Full list of author information is available at the end of the article
Janeiro,Faculdade de Medicina, RJ, Brazil. ${ }^{4}$ Instituto de Medicina Tropical Alexander von Humboldt, Universidad Peruana Cayetano Heredia, Lima, Peru. ${ }^{5}$ Institute of Tropical Medicine, Antwerp, Belgium.

Published: 6 June 2011

doi:10.1186/1742-4690-8-S1-A80

Cite this article as: Arruda et al:: Association between Human T-Cell Lymphotropic Virus Type 1 and 2 (HTLV 1/2) infection and tuberculosis: systematic review and meta-analysis. Retrovirology 2011 8(Suppl 1):A80.
Submit your next manuscript to BioMed Central and take full advantage of:

- Convenient online submission

- Thorough peer review

- No space constraints or color figure charges

- Immediate publication on acceptance

- Inclusion in PubMed, CAS, Scopus and Google Scholar

- Research which is freely available for redistribution

Submit your manuscript at www.biomedcentral.com/submit
( Biomed Central 